DOI: $10.22616 /$ j.balticsurveying.2018.017

\title{
CONCEPTUAL ISSUES OF MODERN LAND MANAGEMENT OF BELARUS
}

\author{
Andrey Kolmykov \\ Belarussian State Agricultural Academy
}

\begin{abstract}
The purpose of this scientific research is to reveal the theoretical foundations of modern land management and determine its tasks. The patterns of land management, its tasks and principles are formulated in the conditions of modern agrarian reform. The system of interconnected forecasting and design of land management development is proposed. The methodological and theoretical basis of research is a dialectical method and a systematic approach to the cognition of economic phenomena and processes. According to this method, all objects are viewed not in isolation, but in a reciprocal relationship and in the process of constant development. In the course of the research, monographic, abstract-logical methods, a system approach, comparative analysis, and expert assessments were used. The scientific research is based on the development of domestic scientists, the experience of land management in the Republic of Belarus, land-cadastral data, normative and reference literature. As a result of the research, it was established that in the conditions of the agrarian reform carried out in the Republic of Belarus land management is an effective mechanism for implementing state policy in the field of land management, regulation of land relations, organization of use and protection of land. Modern land management, based on the state strategy of land reforms, should have a concept of its development based on the laws, which were set in the work, as well as successful solve these problems. For the successful solving of the problems, it is important to revive the previously existing system of forecast and project of land management development in an improved form.

Key words: land reform, land relations, land management, regularities, project design.
\end{abstract}

\section{Introduction}

In conditions of the ongoing agrarian reform in the Republic of Belarus, land management remains the most important part of its economic mechanism. Land management is an instrument of state land resource administration, redistribution among sectors of the national economy, land relations reforming, introduction of new forms of land management, formation of new land users, organization of effective use and protection of land, and intra-farm organization of the territory of agricultural organizations.

General coordination of land use activities in the Republic of Belarus is effected by the State Committee on Property of the Republic of Belarus, and direct land use-planning is handled by land surveying organizations, head departments of land development of administrative areas and land resource management agencies of administrative districts. Land use activities aim at regulating and improving land matters, efficiency improvement of use and protection of land.

The number of employees engaged in land-use system, enterprises under the command of the State Committee on Property of the Republic of Belarus accounts for 1542 people, and that of local landuse offices comes to 1344 .

Land management provided in the Republic can be divided into interfarm and intrafarm one. Objects of land-use planning and control include all lands of the Republic of Belarus, land boundaries as well as plots of land irrespective of the form of their ownership (The Code..., 2008).

In the process of land management, specialists develop relevant planning documentation including geography-specific land-use and land conservation patterns, land management schemes of administrative-territorial and geographical units as well as territories under state protection, interfarm and intrafarm land regulation schemes, organization and arrangement of land areas of different territorial entities, projects connected with land protection and land reclamation.

At present works associated with interfarm land tenure prevail in the Republic. They consist in developing schemes of granting of land plots, execution of technical documentation, establishment of the site boundaries of land plots due to formation of agricultural and nonagricultural land utilization. However, the development of intra-farm land tenure aimed at organization of efficient agricultural 
production, utilization and protection of lands within the boundaries of particular agricultural organizations, farm enterprises, household plots, instructional and other farms should be of prime concern.

Land use planning theory and methods are articulated in scholarly papers of number of scientists (Volkov, 1998; Komov, 2001; Wild, 2003; Chigbu, Kalashyan, 2015; Cowell, Owens, 2016; Harrison, 2017), but they do not make much of conceptual issues of modern land utilization ensuring a higher efficiency of land use. At the same time, within a market economy accompanied by changing market conditions, increase in technogenic character of agricultural production, growth of energy consumption and environmental spoiling a need arises to enhance methodological background of land management, to adjust it to current economic environment and land relations.

The purpose of the study is to show theoretical background of modern land management of the Republic of Belarus and the challenges facing it.

Application of the proposed methodological provisions in land management will provide scientific validation of carrying out land reforms, will be instrumental in laying the organizational-territorial, economic and ecological groundwork for efficient land utilization.

\section{Research methodology and materials}

The dialectical method and systematic approach to the cognition of economic phenomena and processes, according to which all objects are considered not in isolation, but in mutual connection and in the process of constant development, is the methodological and theoretical basis of research. While conducting the research, the following methods were used: monographic, abstract-logical, systems approach, comparative analysis, expert assessments.

Studies of domestic and international scientists on land economies and land management, experience of the republic in the development of land-use project documentation, land-cadastral data, statutory and information materials, guidelines for organization of agricultural production, use and protection of lands, first-hand observations of the author were taken as a basis for the scientific inquiry.

The research work was based on the analysis of land use records, land surveying documentation, data of opinion polls and other information.

\section{Discussion and results}

According to the Land Code of the Republic of Belarus, land management is a set of measures for land inventory, land use planning, establishment (restoration) and fixing of boundaries of land management facilities, and other land management measures aimed at increasing the efficiency of land use and its protection (The Code..., 2008).

Modern land management as a socio-economic phenomenon has deep historical roots. Already in the XVII century, it solved boundary, statistical, cartographic, land-registration and other problems (Shuleikin, 1933). Despite the socio-economic changes in the society, the solution of these issues remains important.

At present, with the transition of the national economy of Belarus to the market economy, the role of land management in the country is growing. The solution of new land management challenges requires the perfection of scientific approaches, consideration of theoretical aspects of modern land management.

The implementation of land reform in Belarus is ensured by the Land Code of the Republic of Belarus (1999 and 2008) (Code of...1999; The Code..., 2008), Presidential Decree № 667 of December 27, 2007 "On seizure and allocation of land plots" (Decree..., 2009) and other normative and legal acts. They formulate in general terms the content and procedure for conducting land management activities. It is emphasized that land administration remains an effective mechanism for implementing land reform, although a separate law on land management has not yet been adopted in the republic.

The most important conceptual provision that governs the regulation of land relations and the implementation of transactions with land is Article 13 of the Constitution of the Republic of Belarus, which states that "... subsoil, water, forests constitute the exclusive property of the state. Land for agricultural use is in a state ownership "(The Constitution..., 2006).

The study of the features of land management in various socio-economic conditions showed that at all stages of land relations it developed on the one hand as a scientific direction studying the patterns of 
functioning and organization of land use and on the other hand, as a practical branch. It always defended the existing land system in the state and was an important tool for regulating land relations. The source and motivating force for improving land management were socio-economic needs, the development of productive forces and the scientific and technological progress of the society.

The overall success of the land administration in implementing its primary role in managing land resources, regulating land relations, organizing the use and protection of land was provided by appropriate legislative acts and technical instructions, supported by reliable financing.

It was revealed that from the historical point of view there are certain regularities in the development of land management, which are as follows:

- conformity of land management to the stage of development of productive forces and social and economic relations;

- maximum consideration of socio-economic and natural conditions, existing settlement, location of economic centers, main roads and other engineering facilities of the territory when organizing the use and arrangement of lands;

- as the socio-economic relations that determine the conditions of management on the land are constantly changing, so land management as a planned reorganization of land relations and organization of land use is also changing, that is, it is in constant motion, will never end or cease. Continuity of land management in general and intra-farm land management in particular is achieved by the introduction necessary changes and clarifications into its projects in connection with the changes in socio-economic conditions in the development of agricultural production in a certain period;

- complexity of land management. Land management not only organizes the use and protection of lands, creates territorial conditions for conducting effective agricultural production, introduction of advanced systems and methods of management, but also arranges people on the territory, creating favorable working and living conditions for the rural population;

- inheritance and continuity of land management. Current land management does not reject the previously existing material forms of the arrangement of engineering facilities of the territory, and the settlement, but, on the contrary, seeks to inherit and adapt everything valuable for use in the new socio-economic conditions.

Considering the importance of modern land management in the regulation of land relations and land management, it is possible to formulate the tasks of modern land management:

- implementation of state policy in the field of land relations, organization of use and protection of land;

- maintaining the legal order in the field of land use;

- activities aimed at increasing the efficiency of land use and protection; ensuring the targeted use and protection of lands, the formation and location of economically and environmentally sound land use;

- creation of territorial conditions for effective agricultural production;

- conservation of sustainable natural landscapes and environmental protection;

- updating of planning and cartographic materials, land inventory and maintenance of reliable qualitative and quantitative accounting;

- the use of geo-information technologies in land management;

- the development of the theory and practice of land management and methodological support for its implementation;

- scientific substantiation of land reforms and forecasting of consequences of land redistribution;

- establishment (restoration) and fixing the boundaries of land management objects.

The solution of the tasks is provided by land management actions, stipulated by the Land Code of the Republic of Belarus (The Code..., 2008), Decree of the President of the Republic of Belarus (Decree..., 2009), which include:

- $\quad$ the development of regional project schemes for the use and protection of land resources, schemes for the land management of administrative-territorial and territorial units, territories of special state regulation;

- the development of inter-farm land management projects, including land allotment projects, 
registration of technical documentation and establishment (restoration) of the boundaries of land management facilities on the terrain;

- the development of projects for in-farm land management of agricultural organizations, including peasant (agricultural) farms, projects for organizing and arranging settlements, horticultural associations, country cooperatives, special protected natural areas and other territorial units;

- the development of projects for land reclamation, soil protection from erosion and other harmful impacts, conservation and improvement of soil fertility and other useful properties of lands, as well as other projects related to the protection and improvement of land;

- the inventory of lands, systematic identification of unused land or used for non-designated purposes;

- geodesic and cartographic works, soil, geo-botanical and other studies and surveys carried out for the purposes of land management, preparation of cadastral and other thematic maps (plans) and atlases of the state and use of land resources;

- author's supervision over the implementation of land management schemes and projects;

- the implementation of land management activities in land monitoring, state land cadaster, including the cadastral valuation of land, land parcels, the implementation of state control over the use and protection of land;

- implementation of research and development activities, as well as the development and modernization of the hardware and software required for land management activities;

- preparation of land management materials to resolve land disputes".

Assuming that land management is a "complex of measures for inventory of land, land use planning, establishment (restoration) and fixing the boundaries of land management objects, conducting other land management measures aimed at increasing the efficiency of land use and protection" (Decree..., 2009), and includes the relevant pre-planning, pre-project and project developments for the organization of land use and protection, and summarizing the existing theoretical developments and many years of land management experience, it is possible to formulate the following main methodological principles:

- a nationwide nature of land management;

- public need for land management as part of the economic mechanism of the Republic in restoring order on the land, regulating land relations, organizing and structuring the territory;

- the rule of law when carrying out land management;

- public interests and interests of land users when carrying out planning activities;

- consideration of natural, economic and social conditions;

- priority of conservation and agricultural land uses of land redistribution;

- integrated nature of planning and production;

- $\quad$ sustainability of land use;

- creation of favorable working and living conditions for the rural population;

- reorganization of land use and reorganization of the territory of agricultural organizations should be carried out on the basis of schemes and land management projects;

- land management should link land reforms with the mechanism of economic incentives for the effective use and protection of land;

- economic, environmental and social efficiency of land management activities.

All of the above principles should be respected in a comprehensive and interrelated way.

In order to solve successfully the tasks faced by modern land management and to deepen the scientific substantiation of land management measures, it is necessary to develop further the proposed methodological foundations of modern land management in Belarus, taking into account changes in the social and economic conditions of the Republic.

The important component of the theoretical provisions of modern land management is organizational territorial, economic and ecological-energy basis for increasing the efficiency of agricultural land use in the agro-industrial complex of the republic.

Organizational and territorial conditions presuppose the optimization of land use of the agricultural organization, the elimination of its territorial shortcomings, the establishment of the optimal size and rationalization of land use of economic and production centers, other elements of the engineering facilities of the territory, determining the optimal composition and ratio of agricultural land and crop 
rotation, establishing their territory, ratio of the size of the territory and the production of the organization.

The economic background for increasing the efficiency of agricultural land use includes optimization of the agricultural production specialization, measures to increase land fertility and crop yields and reduction of the production costs by improving the organizational and territorial conditions of land use.

Ecological and energy principles contribute to the solution of ecological land use in the organization of land and crop rotations and the introduction of ecological and technological energy efficient crop rotations.

According to the Register of Land Resources of the Republic of Belarus (as of January 1, 2018), the total area of the country's lands amounted to 20760.0 thousand hectares. State property is 20683.2 thousand hectares, or $99.6 \%$ of the country's land fund, in private ownership -76.8 thousand hectares, or $0.4 \%$ (Register..., 2018). Consequently, the objects of land management are the land and land plots of these forms of ownership.

The land reform carried out in the country touched mainly agricultural land. At the same time, in the last decade, the focus of land management has been on the formation of new land uses, the consolidation of their boundaries on the terrain and legal registration, the creation of the information database on land (IDL), the optimization of land use, cadastral valuation of lands, the development of the Geoportal of the land information system of the Republic of Belarus.

Without denying the importance of carrying out these land management measures, it should be noted that, in economic significance, they are inferior to actions related to land use optimization, territorial organization of agricultural production and land protection.

It is obvious that modern land management of the Republic as a whole should be based on a clearly developed strategy of land reforms and have a scientific concept of its development, be an effective tool of identification of the state in managed land resources, regulating land relations, reforming agriculture, resolving a complex of environmental, social, economic and other tasks and be carried out in a planned manner by use of the latest cartographic materials, soil data, geo-botanical and other surveys, cadastral valuation of land and geo-information technologies.

The main directions of the use and protection of
land resources of the republic

Fig. 1. The system of forecasting and project land management developments 
The on-farm land management system should play an important role in the organization of rational land use and protection, increasing the efficiency of agricultural production, in the process of which territorial conditions for rational management, energy and resource saving, green land use, improvements in working and living conditions of the rural population are created. Almost every agricultural organization should have modern designs for on-farm land management, which in most cases doesn't exist currently.

To improve the land management of the Republic, to organize the rational use and protection of agricultural land, it is necessary to restore the existing system of land development measures in an updated manner, including the issues of ecological land use and bioenergy approaches to the organization of land use, which will exclude negative impact on the results of land management decisions, market and disparity of prices on agricultural products and material and technical resources consumed in agriculture.

The updated system of land-use forecasting and design development can be presented in the following form (Figure 1).

National strategy of sustainable economic and social development of the Republic of Belarus (National strategy..., 2004), government programs in the field of use and protection of land and other forecast pre-plan documents are to become the methodological framework of building such a system. The presented system of land management development will provide the informed solution of both general and specific tasks of modern land management and its improvement.

Thus, conceptual issues of modern land management of the Republic involve maintaining of the State Land Cadastre, developing land relations, improving the system of long-range and project-oriented land surveying schemes, designed to enable land use planning; carrying out of measures aimed at enhancement of efficiency of government control and administration in the field of use and protection of land at the primary and basic administrative-territorial level, as well as improving land utilization and land protection efficiency. Priority growth area of information technologies in the field of land management for the next few years is improving the Geoportal of land management information system of the Republic of Belarus.

\section{Conclusions and suggestions}

Summarizing the above, the following should be said. 1. In the context of the agrarian reform, which is being carried out in the Republic of Belarus, land utilization system is a practical mechanism of implementing the state policy in the field of land management, land regulation, organization of the use and protection of land. 2. Modern land utilization system based on the national strategies of land reform should have a development concept centered around the above mentioned regularities and take into account tasks and methodological principles of its implementation. 3. To solve the problems faced by modern land utilization system it is important to revitalize the previous system of prognostic and project-oriented land use engineering in better form. 4. Using up-to-date system of prognostic and project-oriented land use engineering will contribute to improving land utilization system of agricultural organizations of the Republic of Belarus.

\section{References}

1. The Code of the Republic of Belarus on Land No. 425-3 of July 23, 2008 (as amended on January 22, 2013) (as amended and supplemented, effective from December 31, 2014).- [Electronic resource] (National legal Internet-portal of the Republic of Belarus -09.01.2015 - No. 2/2228) (in Russian).

2. Code of the Republic of Belarus on land (1999). Goskomzem, Minsk. 72 p. (in Russian).

3. The Constitution of the Republic of Belarus of 1994 (as amended and supplemented, adopted in 2004) (2006) Amalfea, Minsk. 48 p. (in Russian).

4. Decree of the President of the Republic of Belarus, December 27, 2007 No. 667. (2009). On the seizure and provision of land. Center for training, advanced training and retraining of personnel in land management and cartographic-geodesy services, Minsk. 104 p. (in Russian).

5. Kolmykov A.V. (2013). Land management in organization of rational use of agricultural land: monograph. BGSHA, Gorki. 337 p. (in Russian).

6. Shuleikin I.D. (1933). History of land relations and land management. "Selkhozizdat", M.-L., 448 p. (in Russian).

7. Register of Land Resources of the Republic of Belarus (2018) State Property Committee of the Republic of Belarus, Minsk. 57 p. (in Russian). 
8. National strategy of sustainable economic and social development of the Republic of Belarus for the period until 2020 (2004). National Commission on sustainable socio-economic development of the Republic of Belarus; ed. board: Ya.M. Aleksandrovich [et al.]. "Yunipak". Minsk. 202 p. (in Russian).

9. Volkov S.N. (1998). Land utilization system under the conditions of land reform (economy, ecology, law). "Bylina", Moscow. 528 p. (in Russian).

10. Komov N.V. (2001). Guide to land use planning: manual of practice. N. V.Komov, A.Z. Rodin. "Yunipress", Moscow. 394 p. (in Russian).

11. Wild A. (2003). Soils, land, and food: managing the land during the twenty-first century. Cambrige University Press. New York. 246 p.

12. Chigbu U. E., Kalashyan V. (2015). Land-use planning and public administration in Bavaria, Germany: Towards a public administration approach to land-use planning. Geomatics, Landmanagement and Landscape. Number 1. p. 7-17.

13. Cowell R., Owens S. (2016) Land use planning. The EU Referendum and the UK Environment: An Expert Review. p. 57-68.

14. Harrison A. J. (2017) Economics and land use planning. Routledge. 252 p.

Information about authors

Andrey Kolmykov is a Doctor of Economic Sciences, Professor, First pro-rector of Belarusian State Agricultural Academy. Contact details: Faculty of Land Management, Belarusian State Agricultural Academy, Michurina 5, Gorki, Mogilev region 213407, Republic of Belarus, e-mail: kolmykov@tut.by , tel.: +375 029 6921766 (mobile); +3752233 79656 (office). 